\title{
Molecular Diversity of Bacillus thuringiensis and Bioinformatics Analysis of Local Isolate of Auky Island, Padaido District in Biak Numfor Papua as a Control of Anopheles Mosquito Larvae
}

\author{
Daniel Lantang $(\mathbb{D})$ and Arsyam Mawardi* (D) \\ Department of Biology, Faculty of Mathematics and Natural Sciences, Cenderawasih University, \\ Jayapura 99351, Papua, Indonesia.
}

\begin{abstract}
This research aims to analyze the level of similarity and diversity among local isolates of $B$. thuringiensis Auky Island Padaido District in Biak Numfor Regency with NCBI gene bank base, the basis of which is to obtain B. thuringiensis isolates from jayapura local isolates that can act as controllers of Anopheles mosquito larvae. Several steps in the research are $16 \mathrm{~s}$ gene amplification, PCR product purification, cloning using PTA2 vectors and transformation into competent $E$. coli Zymo $5 \alpha$ cells, confirmation with PCR colonies, recombinant plasmid isolation, sequencing analysis and phylogenetic tree construction. The isolates of ABNP8, ABNP9, ABNP11, ABNP12 and ABNP18 have been detected as local isolates from in Auky Island Padaido District in Biak Numfor Papua Regency that have great potential as bioinsecticides, and capable of controlling and killing Anopheles mosquito larvae. Of the five isolates, ABNP8 isolates had unique diversity and characteristics and were different from the four other isolates. Based on the similarity analysis in the MEGA7 program, the similarity rate reached $84 \%$. Its diversity can be seen from the uniqueness of the sequence and its position in different branching dendrograms.
\end{abstract}

Keywords: Anopheles, Bacillus thuringiensis, Genetic diversity, Auky Island, local isolates, Larva controller

*Correspondence: mawardiarsyam@gmail.com; +62 85239558242

(Received: October 12, 2020; accepted: August 19, 2021)

Citation: Lantang D, Mawardi A. Molecular Diversity of Bacillus thuringiensis and Bioinformatics Analysis of Local Isolate of Auky Island, Padaido District in Biak Numfor Papua as a Control of Anopheles Mosquito Larvae. J Pure Appl Microbiol. 2021; 15(4):2295-2301. doi: 10.22207/JPAM.15.4.52

(c) The Author(s) 2021. Open Access. This article is distributed under the terms of the Creative Commons Attribution 4.0 International License which permits unrestricted use, sharing, distribution, and reproduction in any medium, provided you give appropriate credit to the original author(s) and the source, provide a link to the Creative Commons license, and indicate if changes were made. 


\section{INTRODUCTION}

Bacillus thuringiensis, which is one of the many facultative anaerobic bacteria, can produce spores, has gram-positive properties, and is an indigenous bacterium in soil, water, plant surfaces, dead insects, and seeds ${ }^{1}$. This bacterium is known to be able to encode crystalline proteins (cry proteins) during the sporulation period ${ }^{2}$. In order to obtain new $B$. thuringiensis isolates capable of producing cry proteins, the isolation process of several $B$. thuringiensis isolates has been transformed into routines in many industries ${ }^{2}$. B. thuringiensis has been studied and is known to have a wide specificity in various orders of insects which include Lepidoptera, Diptera, Coleoptera, Hymenoptera, Homoptera, Mallophaga and Acari ${ }^{3}$. Most $B$. thuringiensis isolates are known as biopesticide agents which have very high selling points ${ }^{4}$. These bacteria also scientifically qualify as agents for microbiological control of all pests and disease-causing vectors in agriculture ${ }^{5}$.

There are a variety of ways to control Plasmodium parasite vectors, some chemically use insecticide chemical compounds, but using chemicals in excessive and sustainable portions has the potential to kill predators and other living things, so it is important to change methods that are safe for the environment and prioritize the environment safe ${ }^{6}$. Methods that can be done to eradicate mosquitoes and are safe for the environment is to use Bacillus thuringiensis. Bacillus thuringiensis agent is very good at controlling larvae of Anopeheles and safe for humans and non-target organisms. Research on toxicity and the ability to act as bioinsecticides from Bacillus thuringiensis has been extensively studied. This study was intended to obtain $B$. thuringiensis from Jayapura local isolates which have a similarity level among several $B$. thuringiensis isolates obtained, and to compare them with NCBI data. The importance of this research is to obtain a potential picture of $B$. thuringiensis local isolates in Auky Island Padaido District in Biak Numfor Papua Regency as a biological control of Anopheles mosquito larvae.

RESEARCH METHODS

Research location and time

This research was conducted at the Microbiology Laboratory, Department of Biology,
Faculty of Mathematics and Natural Sciences, Cenderawasih University, Jayapura. The sequencing process was carried out in the PT Genetics Science laboratory. The time of the research is June-August 2019.

\section{Amplification of $16 \mathrm{~S}$ genes by PCR}

The $16 \mathrm{~S}$ gene was amplified using the PCR method. The total volume of the master mix is $90 \mathrm{~L}$ divided into five tubes. The primers used are 16S rRNA primers (forward: 5 'AGA GTT TGA TCC TGC CTC AG 3', and reverse: 3 'ACG GCT ACC TTG TTA CGA CTT $5^{\prime}$ ). The DNA of PCR products was purified by Zymoclean Gel DNA Recovery Kit from Zymo Research, and then ligated and transformed in the $16 \mathrm{~S}$ gene cloning process.

Toyobo pTA2 plasmid ligation and transformation to $E$. coli Zymo $5 \alpha$ competent cells

The ligation process of Gen16 is conducted through the making of ligation reaction on ice consisting of $1 \mu \mathrm{L}(0.05 \mathrm{pmol})$ pTA2 vector cloning (50 ng/ $\mu \mathrm{L}), 1 \mu \mathrm{L}$ T4 DNA ligase (1-3 U/ $\mu \mathrm{L}), 16 \mathrm{~S}$ of purification results $3 \mu \mathrm{L}$, and $2 \mathrm{x}$ rapid ligation buffer as much as $5 \mu \mathrm{L}$. Next, the solution went through divortex and centrifuged process for 3-5 minutes. The result of ligation process then incubated at temperature $\left(4^{\circ} \mathrm{C}\right)$ for 18 to 24 hours ${ }^{7}$. Eventually, it was transformed by through Sambrook method ${ }^{8,9}$.

PCR colony and recombinant plasmid isolation

Positive colonies containing $16 \mathrm{~S}$ Genes were amplified by PCR using T3 and T7 KOD FX Neo (Toyobo) primers at annealing temperature of $56^{\circ} \mathrm{C}$. Isolation of recombinant plasmid using ZR Plasmid MiniPrep (Zymo Research)

\section{Sequencing analysis and phylogenetic tree construction}

The raw data from the sequencing was edited with the Seqtrace 0.9 .0 program $^{10}$ and Bioedit 7.2.5 $5^{11}$. Next, homologous species were searched based on its $16 \mathrm{~S}$ gene sequences on $\mathrm{NCB}^{12}$. From the BLAST result, we selected species similar to Bacillus thuringiensis isolate Jayapura to be collected/inserted in one group. Sequence of consensus area $16 \mathrm{~S} B$. Thuringiensis isolates Jayapura and sequences from NCBI were dialigned by the Muscle method ${ }^{13}$. The phylogenetic tree construction uses the Neighbor Joining algorith $\mathrm{m}^{14}$, with a bootstrap value of 1000 in the MEGA version 6 program ${ }^{15}$. These result of 
this process then presented through narrative descriptive to provide a clear understanding of the research.

\section{RESULT AND DISCUSSION}

\section{Results of PCR amplification with 165 primers}

The amplification process with 16S primary primer uses the colony PCR method with annealing temperature of $56^{\circ} \mathrm{C}$. The amplified 16S gene was then electrophoresed using agarose gel with a concentration of $1 \%$. The PCR results can be seen in Fig. 1.

At this stage, the $16 S$ gene was successfully amplified, as evidenced by the band pattern profile after electrophoresis with a size of $\pm 1500 \mathrm{bp}$. The $16 \mathrm{~S}$ target gene was successfully detected in five samples, namely codes $1-5$. The visibility of these five samples shows a specific clear, and bright bands. These five samples which detected by the $16 \mathrm{~S}$ gene were proven by the presence of DNA band fragments. Qualitative test uses a standard method namely DNA migration through agarose gel electrophoresis. Several factors that supported the successfulness of the electrophoresis process are: size and conformation of DNA molecules, agarose concentration, electric current, and temperature. Additionally, the DNA fragments also separated in the gel. Thus, the presence of

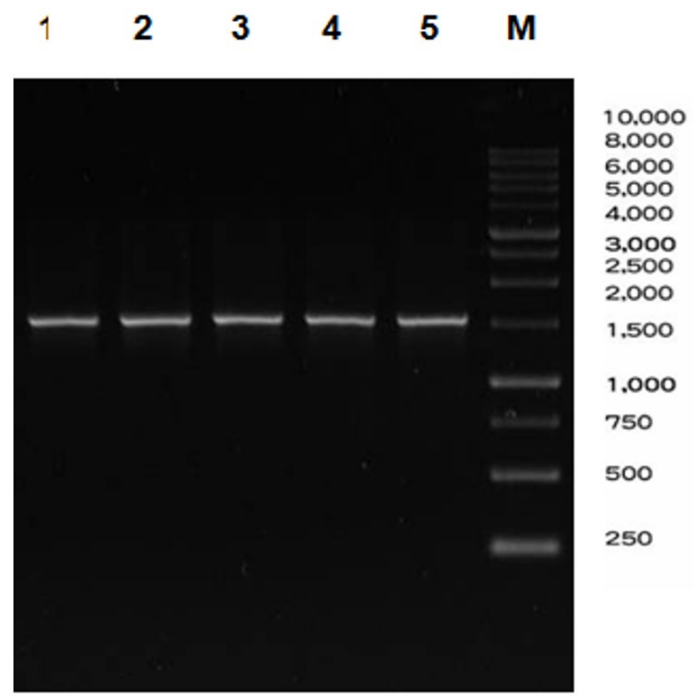

Fig. 1. PCR result of five isolates.

Note: $M$ : Marker DNA ladder $1 \mathrm{~Kb}$, 1-5: sample ABNP8, ABNP9, ABNP 11, ABNP 12, and ABNP18 respectively
$\mathrm{EtBr}$ as a dye will be bound between DNA double strands. The DNA band in agarose will fluoresce because EtBr contains fluorocene. The DNA-EtBr bond will be exposed to UV light so the qualitative test results show that the ribbon profile looks bright. Purified PCR products are prepared with the aim of eliminating all contaminants and potential inhibitors that can prevent the continuation of the cloning process ${ }^{16}$.

The results of cloning to the toyobo pTA2 vector plasmid and transformation to $E$. coli Zymo $5 \alpha$

PCR amplifiers that have been transformed into host $E$. coli ZYMO5a are such that replication can occur when they have become recombinant plasmids. T4 DNA ligase is an enzyme used in the ligation process because it can catalyze the formation of phosphodiester bonds between 3'-OH groups of target DNA fragments and 5'-P groups in vector DNA. The success of cloning is influenced by: (1). Plasmids have an ori role as an initiator in replication, (2) the ampR gene that carries ampicillin resistance, (3) the MCS side helps form new recombinant DNA combinations and (5) the lacZ gene that plays a role in blue white screening. CCMB that is done when competent cell preparation will affect the cell wall and bind DNA to the cell surface ${ }^{17}$. On the other hand ${ }^{18}$ stated that E. coli cells treated with CCMB would be able to take DNA from bacteriophages and plasmid DNA. With the content of ampicillin in the medium, then $E$. coli cells that can grow are cells that only contain PTA2 plasmids because these plasmids have properties that are resistant to ampicillin.

PCR colonies were successfully performed on isolates ABNP8, ABNP9, ABNP11, ABNP12, and ABNP18, with 8 colonies each. ABNP8 isolates showed that most of them produced thick positive bands. Seen the size of $\pm 1.5 \mathrm{~kb}$ of an amplicon that is the same size as the target gene. The profile of the fragment band in the same position as the ladder (marker) is a strong indication of the detection of the $16 \mathrm{~S}$ gene. Positive colonies that do not produce specific bands are caused by false positives, that is, they appear to be positive colonies, but in fact the plasmids do not contain insert genes. In general, confirmation of the presence of $16 \mathrm{~S}$ genes in PTA2 resulting from transformation by PCR colonies was successfully carried out. The tape on the electrophoresis results measuring $\pm 1.5 \mathrm{~kb}$ shows that the $16 \mathrm{~S}$ gene was 
successfully inserted into pTA2. However, to be more convincing and validate the existence of the target gene is correct, then the sample is then sequenced to obtain DNA sequences which will then be aligned with the NCBI database.
Observation of transformant bacterial colonies containing recombinant plasmids

Based on observations, the transformation process was successfully carried out. The key factor to the success of the transformation is the proper

ABNP 8 isolate
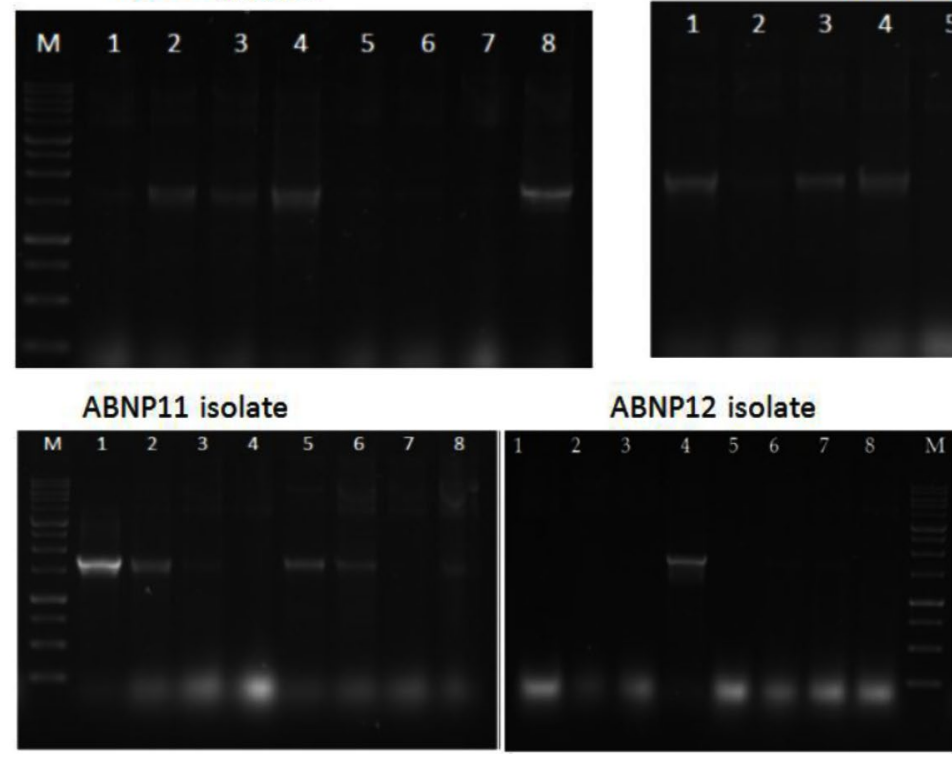

Fig. 2. $P C R$ results from recombinant plasmid $P C R$ colonies

Note: $\mathrm{M}$ : 1Kb DNA ladder markers, 1-8: eight colonies in each ABNP 8, ABNP 9, ABNP 11, ABNP 12, ABNP 18 isolates.

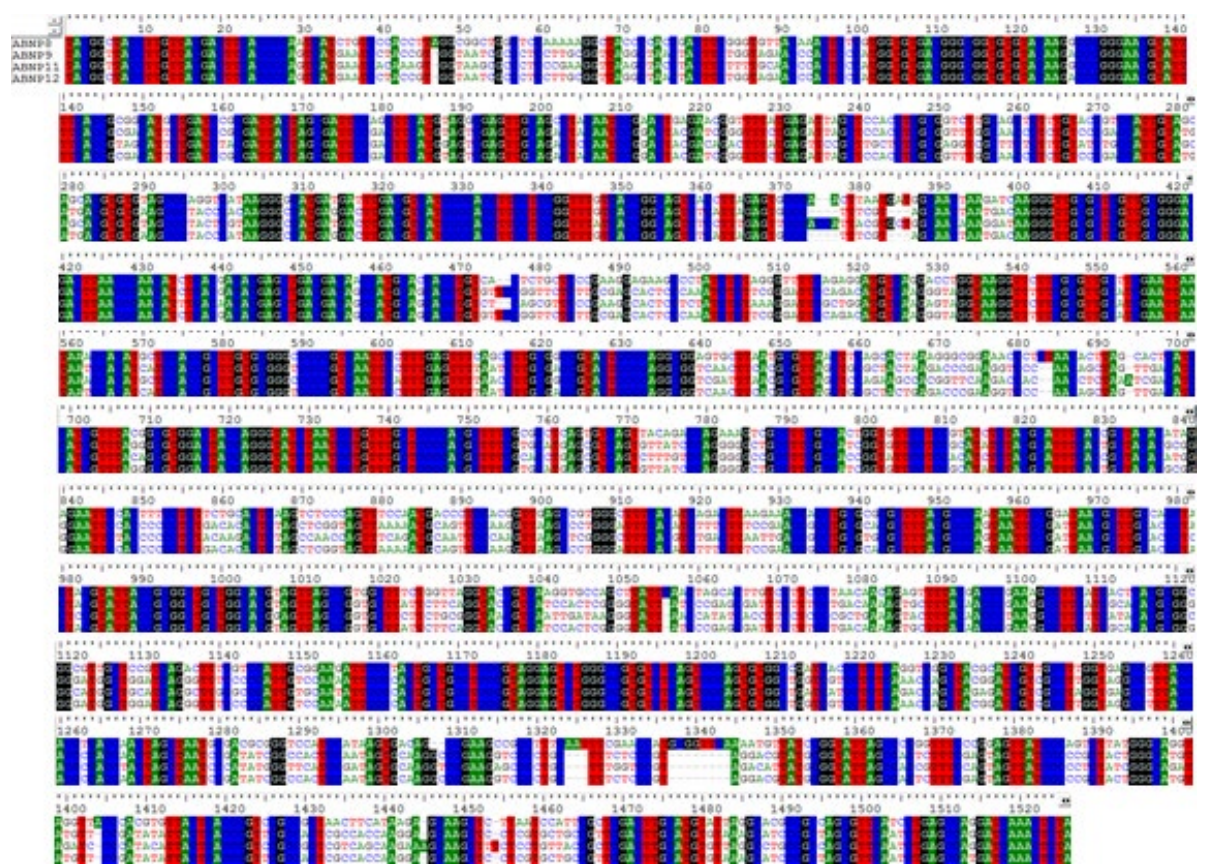

Fig. 3. Results of alignment of five $B$. thuringiensis local isolates from Auky Island Padaido District in Biak Numfor Papua. 
process of heat shock transformation so that the plasmid that has been inserted with the target DNA enters the competent cell. The target colony is a white colony containing transformants, where MCS is inserted by $16 \mathrm{~S}$ fragments so that it is not expressed and causes the colony to remain white. Thus, colonies containing recombinant plasmids are white colonies. Negative control is intended to be able to find out contamination during transformation. To find out the presence of insert genes in an isolated plasmid, it must be confirmed by PCR. The purpose of confirming the transformation results is to know the existence of the $16 \mathrm{~S}$ gene in PTA2. This is also a way to see the successful integration of insert genes in plasmids by using primers that are specific to insert genes. To be more convincing and validate the existence of the insert gene is correct then the sample needs further analysis process, namely by sequencing to obtain the DNA sequence to be aligned with the data bank.

\section{Sequencing analysis}

Sequencing results in the form of chromatograms show a certain spectrum and intensity. The higher the plasmid concentration, the better the spectrum of sequencing results. The size of the target DNA is $\pm 1500 \mathrm{bp}$, so that the sequencing is done in two directions, so that all nucleotide DNA targets can be known. After going through the contig, reverse complement process, DNA sequences without gaps are obtained which are called sustainable areas or consensus. The results of the Multiple Sequence Alignment of some 16S Auky Island Padaido District in Biak Numfor Papua Regency isolates detected showed that Auky Island Padaido District in Biak Numfor Papua Regency local isolates categorized as ABNP8, ABNP9, ABNP11, ABNP12, and ABNP18 had sustainable areas (conserve) or consensus in the same position but adapted areas that varied from size $16 \mathrm{~S} \pm 1500 \mathrm{bp}$. The colored shaded area in Fig. 4 above shows the same nitrogenous bases in all four isolates. Thus the results of preliminary analysis showed that DNA sequences from the 16S B. thuringiensis marker gene in Auky Island Padaido District in Biak Numfor Papua Regency local isolates were detected as different isolates, in addition to those previously discovered by many researchers.

\section{Phylogenetic tree construction results}

Phylogenetic tree construction is intended to know phylogeny and show evolutionary relationships between organisms (kinship relationships), where the sample has properties similar to the closest relatives because of a kind. To

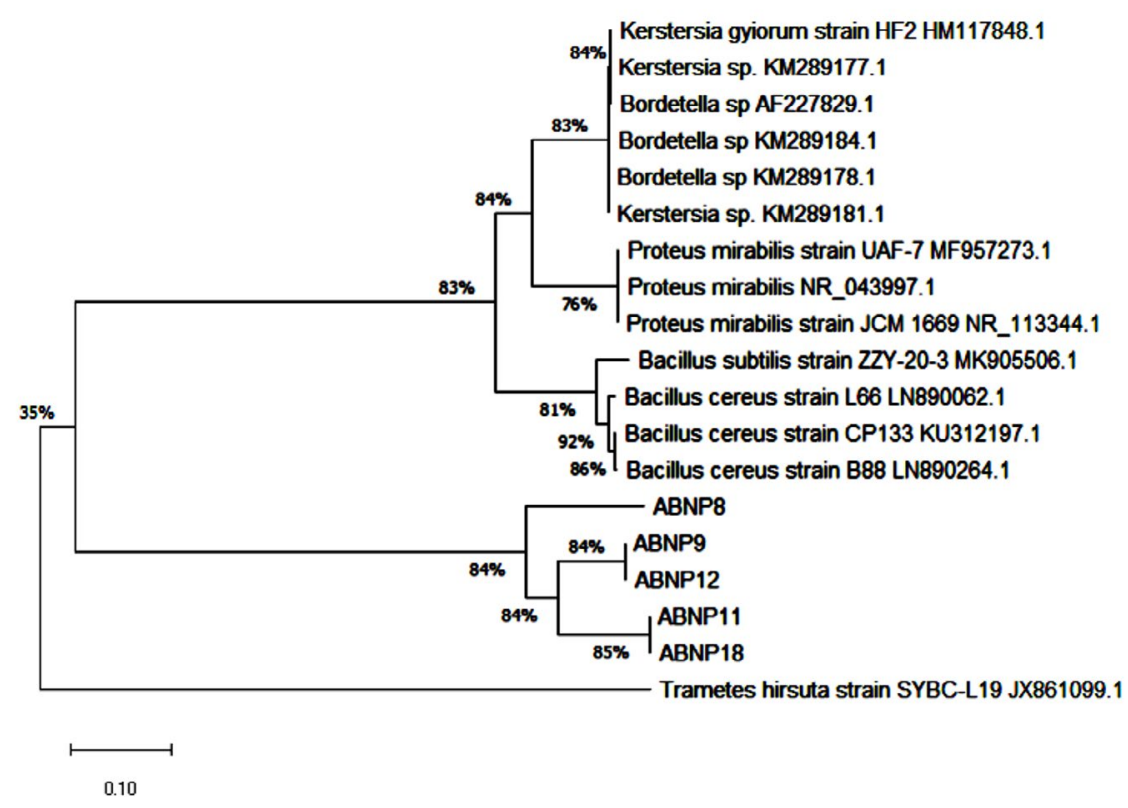

Fig. 4. Phylogenetic tree B. thuringiensis local isolate Auky Island Padaido District in Biak Numfor Papua Regency. 
carry out phylogenetic tree construction analysis in this study, outgroups were determined at different levels with all sequences compared ${ }^{19}$.

Based on the input data in the MEGA 6 program, a phylogenetic tree construction was obtained which illustrates the similarity between fellow Bacillus thringiensis Auky Island Padaido District in Biak Numfor Papua Regency isolates and the kinship of several isolates in the gene bank database. In this Fig., 4 large clusters were formed, namely from various isolates randomly located in one cluster. It can be seen in Fig. 3 that based on the $16 \mathrm{~S}$ gene markers, successfully placed isolates ABNP8, ABNP9, ABNP11, ABMP12, and ABNP18 are in one cluster with $84 \%$ safety percentage showing credibility, consistency and degree of robustness from its position in the phylognetic tree. Specifically ABNP8 has specificity because it is separate and has its own branching between other Jayapura local isolates namely ABNP 9, ABNP11, $A B N P 12$, and $A B N P 18$. It is very interesting that there is a possibility that ABNP8 isolates are really different, have diversity or combination alleles that cause variation, while isolates in the NCBI gene database such as Kerstersia, Bordetella and proteus in other clusters. Likewise, Bacillus cereus and Bacillus subtilis are located in the same cluster with a similarity percentage level reaching mencapai $80 \%$. Phylogenetic trees are also intended to find out phylogeny, where samples that have similar properties will be in an adjacent position because they have identical DNA sequences or have many similarities. In this phylogenetic tree, outgroups are determined to be at different levels with all the sequences compared, namely Trametes hirsuta, in different clusters from the 3 previous clusters, because Trametes hirsuta has been positioned as outgroup samples that are indeed different at the species level. The phylogenetic tree was constructed using the Neighbor Joining algorithm method, and a bootstrap value of 1000

\section{CONCLUSION}

Based on the results of research that has been done, it can be concluded as follows: The isolates of ABNP 8, ABNP9, ABNP11, ABNP12 and $A B N P 18$ have been detected as local isolates from Auky Island Padaido District in Biak Numfor Papua Regency that have great potential as bioinsecticides to control and kill the Anopheles mosquito larvae. The similarity of the five isolates reach $84 \%$ based on MEGA7 program. Of the five isolates, ABNP 8 isolate had an unique characteristics and diversity compared to the other four isolates.

\section{ACKNOWLEDGMENTS}

We thank to PT. Genetika Science where sample were sequenced using Sanger sequencing.

\section{CONFLICT OF INTEREST}

The authors declare that there is no conflict of interest.

\section{AUTHORS' CONTRIBUTION}

All listed author(s) have made a substantial, direct and intellectual contribution to the work, and approved it for publication.

\section{FUNDING}

This study was supported by Cenderawasih University Research and Community Service Institute.

\section{DATA AVAILABILITY}

All datasets generated or analyzed during this study are included in the manuscript.

\section{ETHICS STATEMENT}

This article does not contain any studies with human participants or animals performed by any of the authors.

\section{REFERENCES}

1. Kawalek MD, Benjamin S, Lee HL, Gill SS. Isolation and Identification of Novel Toxins from a New Mosquitocidal Isolate from Malaysia, Bacillus thuringiensis subsp. jegathesan. Appl Environ Microbiol. 1995;61(8):29652969. doi: 10.1128/AEM.61.8.2965-2969.1995

2. Bravo A, Sarabia S, Lopez L, et al. Characterization of cry genes in a Mexican Bacillus thuringiensis strain collection. Appl Environ Microbiol. 1998;64(12):49654972. doi: 10.1128/AEM.64.12.4965-4972.1998

3. Kuo W-H, Chak KF. Identification of novel cry-type genes from Bacillus thuringiensis strains on the basis of restriction fragment length polymorphism of the PCR-Amplified DNA. Appl Environ Microbiol. 1996;62(4):1369- 1377. doi: 10.1128/AEM.62.4.13691377.1996

4. Lopez-Meza JE, Ibarra JE. Characterization of a Novel Strain of Bacillus thuringiensis. Appl Environ Micorbiol. 1996;62(4):1306-1310. doi: 10.1128/AEM.62.4.1306- 


\subsection{6}

5. Ben-dov E, Wang Q, Zaritzky A, et al. Multiplex PCR screening to detect cry9 genes in Bacillus thuringiensis strains. Appl Environ Microbiol. 1999;65(8):3714-3716. doi: 10.1128/AEM.65.8.3714-3716.1999

6. Bellows TS, Fisher TW. Handbook of Biological Control. Principles and Applications of Biological Control. Academic Press. New York. 1999. (Book).

7. Toyobo. Instruction Manual Ligation High Version 2. https://www.toyobo-global.com/seihin/xr/lifescience/ products/clon_002.html, Accessed 21 September, 2020.

8. Sambrook J, Fritsch EF, Maniatis T. Molecular Cloning a Laboratory Manual, New York, Cold Spring Harbor Laboratory Press. 1989 (Book)

9. Das S, Dash HR. Microbial Biotechnology-A Laboratory Manual forBacterial Systems. Clim Chang 2013 - Phys Science Basis. 2015;53:1-30. doi: 10.1007/978-81-3222095-4

10. Stucky BJ. SeqTrace: A Graphical Tool for Rapidly Processing DNA Sequencing Chromatograms. J Biomol Tech. 2012;23(3):90-93. doi: 10.7171/jbt.12-2303-004

11. Hall TA. BioEdit: A User-Friendly Biological Sequence Alignment Editor and Analysis Program for Windows 95/98/NT, Nucleic Acids Symposium Series. 1999;41: 95-98.

12. Altschul SF, Gish W, Miller W, Myers, EW Lipman DJ. Basic Local Alignment Search Tool. J Mol Biol.1990;215(3):403-410. doi: 10.1016/S00222836(05)80360-2
13. Edgar RC. MUSCLE: Multiple Sequence Alignment with High Accuracy and High Throughput. Nucleic Acids Research. 2004;32(5):1792-1797. doi: 10.1093/nar/ gkh340

14. Saitou N, Nei M. The Neighbor-Joining Method-a New Method for Reconstructing Phylogenetic Trees. Molecular Biology and Evolution. 1987;4(4):406-425. doi: 10.1093/oxfordjournals.molbev.a040454

15. Tamura K, Stecher G, Peterson D, Filipski A, Kumar S. MEGA6: Molecular Evolutionary Genetics Analysis Version 6.0. Mol Biol Evol. 2013;30(12):2725-2729. doi: $10.1093 / \mathrm{molbev} / \mathrm{mst} 197$

16. Mawardi A, Ramandey ERPF. Malaria-causing MSP-1 Plasmodium falciparum Ligation and Transformation in Jayapura City. Majalah Kedokteran Bandung. 2017;49(4):213 -223. doi: 10.15395/mkb.v49n4.1138

17. Primrose SB, Twyman RM. Principles of Gene Manipulation and Genomics 7th edition. Australia: Blackwell Publishing. 2006 (Book)

18. Liu J, Chang W, Pan L, et al. An Improved Method of Preparing High Efficiency Transformation Escherichia coli with Both Plasmids and Larger DNA Fragments. Indian Journal of Microbiology. 2018;58:448-456. doi: 10.1007/s12088-018-0743-z

19. Mawardi A, Aisoi LE, Lefaan PN. Kloning dan Analisis Bioinformatika Gen 16 S Plasmodium falciparum Isolat Kota Jayapura. Jurnal Biologi Papua. 2018;10(1):1-10. doi: 10.31957/jbp.126 